\title{
HIGH-YIELD PRODUCTION OF A CHIMERIC GLYCOPROTEIN BASED ON PERMUTED E1 AND E2 HCV ENVELOPE ECTODOMAINS
}

Daniel Tello ${ }^{\mathrm{a}, 1}$, Mar Rodríguez-Rodríguez ${ }^{\mathrm{a}, 2}$, Belén Yélamos $^{\mathrm{a}}$, Julián Gómez-Gutiérrez ${ }^{\mathrm{a}}$, Darrell L. Peterson ${ }^{\mathrm{b}}$, and Francisco Gavilanes ${ }^{\mathrm{a},}$ *

a Departamento de Bioquímica y Biología Molecular, Facultad de Ciencias Químicas, Universidad Complutense, Madrid 28040

${ }^{\mathrm{b}}$ Department of Biochemistry and Molecular Biology, Medical College of Virginia, Virginia Commonwealth University, Richmond, Virginia, 23298

* Corresponding author: F. Gavilanes, Departamento de Bioquímica y Biología Molecular, Facultad de Ciencias Químicas, Universidad Complutense, 28040 Madrid, Spain. Phone: (34) 9139442 66. Fax: (34) 9139441 59. E-mail: pacog@,bbm1.ucm.es

${ }^{1}$ Present address: Hospital Universitario Santa Cristina, C/ Maestro Amadeo Vives, 2 y 3, 28009 Madrid

${ }^{2}$ Present address: Hospital Universitario Ramón y Cajal, Ctra. De Colmenar Viejo Km 9,100, 28034 Madrid 


\begin{abstract}
In this report it is described for the first time the expression and purification of large quantities of a soluble and correctly folded chimeric recombinant protein, $\mathrm{E} 2_{661} \mathrm{E} 1_{340}$, containing the permuted Hepatitis $\mathrm{C}$ virus (HCV) glycoprotein ectodomains E1 (aminoacids 192-340) and E2 (aminoacids 384-661). Using the baculovirus/insect cell expression system, $8 \mathrm{mg}$ of secreted protein were purified from $1 \mathrm{~L}$ of culture media, a yield 4 times higher than the described for its counterpart $E 1_{341} \mathrm{E} 2_{661}$. This permuted chimeric protein is glycosylated and possesses a high tendency to selfassociate. The fluorescence emission spectrum indicates that Trp residues occupy a relatively low hydrophobic environment. The secondary structure was determined by deconvolution of the far-UV circular dichroism spectrum yielding 13\% $\alpha$-helix structure, $49 \%$ extended structure and $38 \%$ non-ordered structure. $\mathrm{E} 2_{661} \mathrm{E} 1_{340}$ binds to antibodies present in human sera from $\mathrm{HCV}$-positive patients, a binding that is blocked at different levels by a rabbit anti-E2 ${ }_{661}$ antibody. All these structural and antigenic features of $\mathrm{E} 2_{661} \mathrm{E} 1_{340}$ are very similar to those described for $\mathrm{E} 1_{340} \mathrm{E} 2_{661}$, Thus, this high-yield isolated chimeric protein may be a valuable tool to study the first steps of the HCV infection.
\end{abstract}

Keywords: Hepatitis C Virus, envelope protein, E1, E2, baculovirus, glycosylation 


\section{Introduction}

Hepatitis $\mathrm{C}$ virus $(\mathrm{HCV})$ is a major cause of chronic hepatitis, liver cirrhosis, and hepatocellular carcinoma worldwide (Major et al., 2001). HCV is a positive sense, single-stranded RNA virus belonging to the Hepacivirus genus of the Flaviviridae family. Currently, there is no vaccine for HCV and the antiviral therapy which is used include the use of polyethylene glycol-modified interferon, ribavirin and protease inhibitors although there are also other drugs in phase III of clinical development (Imran et al., 2014). Unfortunately, all the treatments are expensive and are not 100\% effective (Feld and Hoofnagle, 2005).

The HCV envelope glycoproteins, E1 (gp31) and E2 (gp70), are released from the polyprotein coded for by the $\mathrm{HCV}$ genome after cleavage by host-cell endoplasmic reticulum proteases in positions $383 / 384$ and $746 / 747$ of the sequence, respectively (Mizushima et al., 1994). According to the amino acid sequence analysis of E1 and E2, these highly glycosylated glycoproteins are classified as type I integral transmembrane proteins with an N-terminal ectodomain (residues 192-340 and 384661 of the polyprotein for E1 and E2 respectively) and a C-terminal hydrophobic domain anchor. In vitro expression studies have shown that both glycoproteins associate to form a stable non-covalently linked heterodimer, which accumulate in the endoplasmic reticulum, the proposed site for HCV assembly and budding (Op De Beeck et al., 2001). On the other hand, studies carried out using cell-cultured HCV (HCVcc) have shown that the envelope glycoproteins E1 and E2 are able to form large covalent complexes stabilized by disulfide bridges in the virion (Vieyres et al., 2010).

$\mathrm{HCV}$ envelope glycoproteins E1 and E2 play an essential role in virus entry into host cells by interacting with cell surface receptors, and inducing fusion between 
the viral and cellular membranes (Nielsen et al., 2004; Bartosch et al., 2003). E2 is the primary glycoprotein responsible for the interaction with cellular receptors including heparan sulfate, the tetraspanin CD81, the scavenger receptor BI, the tight junction proteins claudin-1 and occludin, the Niemann-Pic C1-like 1 cholesterol absorption receptor and other factors (reviewed in (Ploss and Dubuisson, 2012), while little is known about the exact role of E1 protein. It has been shown that E1 folding (either the ectodomain or the full length protein) is dependent on E2 coexpression (Sandrin et al., 2005; Patel et al., 2001; Michalak et al., 1997), and that full-length E2 folding is also dependent on E1 co-expression (Brazzoli et al., 2005; Cocquerel et al., 2001). These observations indicate that HCV envelope glycoproteins cooperate to form a functional complex.

The difficulty of propagating HCV in cell culture has hampered for many years functional studies on $\mathrm{HCV}$ infection. The cellular mechanism of $\mathrm{HCV}$ entry has been studied using HCV pseudoparticles (HCVpp), infectious retroviral particles with HCV envelope proteins on the surface, and the cell culture model which allows for the production and propagation of virus in cell culture (HCVcc) (Lindenbach and Rice, 2005; Wakita et al., 2005; Zhong et al., 2005). Despite that E1 and E2 have been expressed in several prokaryotic (Hüssy et al., 1997) or eukaryotic (Lorent et al., 2008; Mustilli et al., 1999; Michalak et al., 1997; Hüssy et al., 1996) cell lines, few data concerning to the structure of isolated proteins have been obtained. Most of the structural studies have been focused on the E2 protein, since, contrary to the full-length polypeptide, the E2 ectodomain has been characterized as an independent folding unit (Rodriguez-Rodriguez et al., 2009; Whidby et al., 2009). Thus, very recently, two different groups have described the crystal structure of the E2 core ectodomain in complex with antibodies (Khan et al., 2014; Kong et al., 2013). 
However, attempts to analyse the structure of the E1 ectodomain have been hindered by the impossibility to isolate this protein in a native-like conformation, probably due to the above mentioned folding dependency on E2. In order to overcome this problem, a recombinant chimeric protein containing both E1 and E2 ectodomains connected by a small hydrophilic peptide, $E 1_{341} \mathrm{E} 2_{661}$, has been previously shown to have all the features of a correctly folded polypeptide (Tello et al., 2010). In this work, the cloning, expression and purification of a new chimeric protein based on permuted E1 and E2 ectodomains in a baculovirus/insect cell system is described. Also, the characterization of some structural and functional properties is presented. This chimera was produced with a yield four times that described for $\mathrm{E} 1_{341} \mathrm{E} 2_{661}$. Several criteria indicate that $\mathrm{E} 2_{661} \mathrm{E} 1_{340}$ is correctly folded and processed. Moreover, different biochemical, spectroscopic and antigenic studies indicated that both $\mathrm{E} 1_{341} \mathrm{E} 2_{661}$ and $\mathrm{E} 2_{661} \mathrm{E} 1_{340}$ present a very similar overall $3 \mathrm{D}$ structure. 


\section{Materials and methods}

\subsection{Plasmids constructions}

The E1 and E2 DNA encoding sequences were obtained by RT-PCR from the viral RNA of a HCV1 strain, genotype 1a (Accession number M62321). In order to connect E2 and E1 ectodomains by a flexible, protease susceptible peptide, the E1 gene was subcloned into the pProEx-HTb vector (Life Technologies, Grand Island, NY, USA), which contains the sequence encoding the TEV protease recognition site upstream of the cloning site. For this subcloning, E1 gene was amplified by PCR using the pAcGP67A-E1 ${ }_{340}-\mathrm{E} 2_{661}$ (Tello et al., 2010) vector as template and the

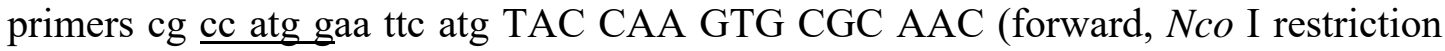
site underlined) and ca gcggecgc tca GAT CCG GAG CAG CTG (reverse, Not I site underlined). The resulting plasmid, $\mathrm{pPROEX}-\mathrm{E} 1_{340}$ was used as template for a second PCR reaction using the same E1 reverse primer and the following forward primer: ga aga tct gat tac gat atc cca cg, thus obtaining a fragment containing spacer-TEV protease sequence preceeding E1, as well as a Bgl II restriction site (underlined). Finally, after a three fragment ligation between a) pAcGP67A-E2 ${ }_{661}$ (RodriguezRodriguez et al., 2009) digested with Nhe I/Not I (contains E2 $384-438$ ), b) the fragment E2 ${ }_{438-661}$, obtained after digestion of pAcGP67A-E1 ${ }_{340}-\mathrm{E} 2_{661}$ with $\mathrm{Nhe} \mathrm{I} / \mathrm{Bgl} \mathrm{II}$, and

c) spacer-TEV-E1 digested with Bgl II/Not I, the recombinant plasmid pAcG$\mathrm{E} 2_{661} \mathrm{E} 1_{340}$ was obtained.

\subsection{Insect cell culture and transfections}

After the culture of insect cell line Spodoptera frugiperda (Sf9) in Insect XPress serum-free media (BioWhittaker, Lonza, Walkersville, MD, USA) at $27^{\circ} \mathrm{C}, \mathrm{Sf9}$ 
cells were cotransfected with Baculogold ${ }^{\mathrm{TM}}$ DNA (BD Biosciences, San Jose, CA, USA) and the recombinant transfer vector pAcGP67A- E2 ${ }_{661} \mathrm{E} 1_{340}$ as indicated by the manufacturer. Baculogold ${ }^{\mathrm{TM}}$ DNA is a modified wild baculovirus DNA which contains a lethal deletion and cannot develop into a viable virus by itself. Recombination between the flanking regions of the polyhedrin gene from the transfer vector and modified wild-type baculovirus DNA therefore results in $100 \%$ recombinant baculovirus DNA. After several rounds of culture amplifiyng the recombinant virus, a high titer virus stock solution was harvested. On a larger scale protein expression, High Five ${ }^{\mathrm{TM}}$ insect cells (Invitrogen, Carlsbad, CA, USA) were grown in Insect X-Press serum-free media prior to infection with high titer virus $\left(>10^{8} \mathrm{pfu} / \mathrm{ml}\right)$ at a multiplicity of infection of $5-10$.

\subsection{Purification of $E 2_{661} E 1_{340}$}

$500 \mathrm{ml}$ of recombinant baculovirus-infected insect cell cultures were harvested approximately $120 \mathrm{~h}$ postinfection and the cells pelleted by centrifugation at $5000 \mathrm{~g}$ for $10 \mathrm{~min}$. The supernatant was dialyzed against $20 \mathrm{mM}$ Tris- $\mathrm{HCl} \mathrm{pH} 7.0$, $50 \mathrm{mM} \mathrm{NaCl}$ and loaded onto a $\mathrm{Ni}^{2+}$-Nitrilotriacetic acid agarose (Ni-NTA-agarose) column (Qiagen, Hilden, Germany) which had been previously equilibrated with the same buffer at a flow rate of $0.5 \mathrm{ml} / \mathrm{min}$. About $3 \mathrm{ml}$ of gel were used per liter of culture supernatant. Once the protein solution had entered the column, it was washed with dialysis buffer containing $10 \mathrm{mM}$ imidazole and later $30 \mathrm{mM}$ imidazole. The recombinant $\mathrm{E} 2_{661} \mathrm{E} 1_{340}$ protein was eluted with $200 \mathrm{mM}$ imidazole in dialysis buffer. The presence of $\mathrm{E} 2_{661} \mathrm{E} 1_{340}$ was monitored by SDS-PAGE throughout the purification. 


\subsection{Protein analysis}

Protein concentration was determined by using the absorbance at $280 \mathrm{~nm}$ and the extinction coefficient calculated from the amino acid analysis. The absorption spectra were recorded on a Beckman DU-640 spectrophotometer (Beckman Coulter, Brea, CA, USA). The amino acid analysis of hydrolyzed aliquots was performed on a Beckman 6300 automatic analyzer (Beckman Coulter, Brea, CA, USA). Approximately, $20 \mu \mathrm{g}$ of purified protein were hydrolyzed with $5.9 \mathrm{~N}$ tridistilled $\mathrm{HCl}$ at $110^{\circ} \mathrm{C}$ for $24 \mathrm{~h}$. Norleucine was used as an internal standard. Automated Edman protein degradation of $\mathrm{E} 2{ }_{661} \mathrm{E} 1_{340}$ was performed using an Applied Biosystems 494 gas-phase sequencer (Life Technologies, Grand Island, NY, USA).

\subsection{Protein Deglycosylation}

Digestion of protein samples with N-glycosidase F (PNGase F, Roche Diagnostics, Mannheim, Germany) was carried out for $16 \mathrm{~h}$ at $37{ }^{\circ} \mathrm{C}$ in $20 \mathrm{mM}$ sodium phosphate $\mathrm{pH} 7.0,50 \mathrm{mM}$ EDTA, and $1 \%(\mathrm{p} / \mathrm{v})$ octylglucoside. Then, digested samples were mixed with $3 \mathrm{X}$ Laemmli sample buffer, analyzed by SDSPAGE and stained with Coomassie brilliant blue R 250. The proteins were also transferred to nitrocellulose membranes that were subsequently incubated with the lectin concanavalin A conjugated to biotin (Pierce, Rockford, IL, USA). The glycoproteins were detected using HRP-streptavidin at a 1:1000 dilution.

\subsection{Circular Dichroism}

CD spectra were recorded with a Jasco spectropolarimeter, model J-715 (Jasco, Easton, MD, USA) at $25{ }^{\circ} \mathrm{C}$ with cells thermostated with a Neslab RTE-111 water bath. Far-UV CD spectra were measured at a protein concentration of 0.15 
$\mathrm{mg} / \mathrm{ml}$ in $20 \mathrm{mM}$ Tris- $\mathrm{HCl} \mathrm{pH}$ 7, $50 \mathrm{mM} \mathrm{NaCl}$. The pathlength was $1 \mathrm{~mm}$. Five scans were averaged for each measurements and the contribution of the buffer was always subtracted. The spectra were calculated by using 110 as the mean residue molecular mass and the results are expressed in terms of residue molar ellipticity in $\mathrm{deg} \cdot \mathrm{cm}^{2} \cdot \mathrm{dmol}^{-1}$. The secondary structure of the protein was evaluated by computer fit of the dichroism spectra according to Convex Constraint Analysis (CCA) (Perczel et al., 1991). This method relies on an algorithm that calculates the contribution of the secondary structure elements that give rise to the original spectral curve without referring to spectra from model systems. The secondary structure was also predicted by the GOR IV method (Garnier et al., 1996).

\subsection{Fluorescence spectroscopy}

Emission spectra were obtained at $25^{\circ} \mathrm{C}$ using an SLM AMINCO 8000C spectrofluorimeter (SLM Instruments, Urbana, IL, USA), fitted with a 450-W xenon arc. Excitation and emission slit widths were set at $4 \mathrm{~nm}$. The protein concentration was $0.05 \mathrm{mg} / \mathrm{ml}$ and a $0.4 \times 1 \mathrm{~cm}$ cuvette was used. Buffer was $20 \mathrm{mM}$ Tris-HCl pH 7, $50 \mathrm{mM} \mathrm{NaCl}$. Excitation was performed at 275 or $295 \mathrm{~nm}$, and the emission spectra were recorded over the range $285-450 \mathrm{~nm}$. The contribution of the buffer was always subtracted. The tyrosine contribution to the emission spectra was calculated by subtracting the emission spectrum measured at $\lambda_{\text {exc }}=295 \mathrm{~nm}$ multiplied by a factor from that measured at $\lambda_{\mathrm{exc}}=275 \mathrm{~nm}$. The factor was obtained from the ratio between the fluorescence intensities measured with $\lambda_{\text {exc }}=275$ and $\lambda_{\text {exc }}=295 \mathrm{~nm}$ at wavelengths above $380 \mathrm{~nm}$, where there is no tyrosine contribution. 


\subsection{SDS-PAGE}

Sodium dodecyl sulfate-polyacrylamide gel electrophoresis (SDS-PAGE) was performed according to Laemmli using 15\% polyacrylamide gels (Laemmli, 1970). Samples were subjected to gel electrophoresis under either nonreducing or reducing conditions (with $5 \%(\mathrm{v} / \mathrm{v}) \beta$-mercaptoethanol) and the proteins were stained with Coomassie brilliant blue R-250. The molecular mass of the protein bands was estimated by comparison with protein markers of known molecular mass (Prestained SDS-PAGE Standards, Bio-Rad, Hercules, CA, USA).

\subsection{Western blotting}

After SDS-PAGE, proteins were transferred to nitrocellulose membranes (Hybond-ECL; Amersham, Piscataway, NJ, USA) in $48 \mathrm{mM}$ Tris-HCl pH 9.0, containing $39 \mathrm{mM}$ glycine, $0.0375 \%$ SDS and $20 \%(\mathrm{v} / \mathrm{v})$ methanol, for $1 \mathrm{~h}$ at 1 $\mathrm{mA} / \mathrm{cm}^{2}$, by using a V20-SDB apparatus (Scie-Plas, Cambridge, UK). To detect $\mathrm{E} 2_{661} \mathrm{E} 1_{340}$, membranes were incubated with a HRP-conjugated monoclonal anti-His (Sigma-Aldrich, St. Louis, MO, USA) at a 1:3000 dilution. The peroxidase reaction was developed with 3,3'-diaminobenzidine tetrahydrochloride $/ \mathrm{H}_{2} \mathrm{O}_{2}$. For recombinant protein detection with the mouse anti-E1 (Acris Antibodies, Herford, Germany) and rabbit anti-E2 ${ }_{661}$ antibodies, nitrocellulose membrane was incubated with these antibodies at 1:1000 dilution with 0.1\% Tween 20 in PBS. Following overnight incubation, the membrane was washed extensively with PBS containing $0.1 \%$ Tween 20. After that, membrane was incubated with a goat anti-mouse or goat anti-rabbit antibodies in each case at 1:3000 dilution for 2 hours. After membrane washing, the immunoblots were developed as described above. 
Polyclonal antibody against recombinant protein, E2 661 (Rodriguez-Rodriguez et al., 2009), was prepared by immunizing New Zeeland white rabbits over a 6-week period by weekly injection of the protein $(100 \mu \mathrm{g})$ in complete Freund's adjuvant.

\subsection{Enzyme Linked Immunosorbent Assay (ELISA)}

96 wells microtitre plates (Corning, Tewksbury, MA, USA)were coated overnight at $4{ }^{\circ} \mathrm{C}$ with $100 \mathrm{ng} /$ well of purified recombinant $\mathrm{E} 2_{661} \mathrm{E} 1_{340}$ or $\mathrm{E} 1_{341} \mathrm{E} 2_{661}$ diluted to $1 \mu \mathrm{g} / \mathrm{ml}$ in $0.05 \mathrm{M}$ carbonate-bicarbonate buffer, $\mathrm{pH}$ 9.6. Unbound antigen was discarded, and the wells were blocked with 3\% non-fat dry milk in PBS for 60 min at room temperature. After washing the wells were incubated at $37^{\circ} \mathrm{C}$ for $2 \mathrm{~h}$ with human serum. Eight HCV-positive human sera and ten HCV-negative human sera were used at a dilution of 1:200. The plates were washed three times with PBS/0.05\% Tween 20 and incubated at $37^{\circ} \mathrm{C}$ for $1 \mathrm{~h}$ with HRP-conjugated anti-human $\operatorname{IgG}(\mathrm{Fc})$ diluted at 1:10000. Bound antibodies were detected by adding $100 \mathrm{mM}$ sodium citrate, $\mathrm{pH}$ 5.0, 4\% Methanol buffer containing $\mathrm{H}_{2} \mathrm{O}_{2}$ and the substrate $O$ phenylenediamine dihydrochloride (Merck, Whitehouse Station, NJ, USA). The optical density at $492 \mathrm{~nm}$ was measured using an ELISA Expert 96 microplate reader (ASYS Hitech, Cambridge, UK). Sera from infected and control patients were provided by Dr. Fernando Vivanco (Fundación Jiménez Díaz, Madrid, Spain). ELISA inhibition assays were performed as described (Cocquerel et al., 2001). After coating with $100 \mu \mathrm{l}$ of antigen $(1 \mu \mathrm{g} / \mathrm{mL})$, the plates were incubated with $\mathrm{HCV}$ infected patients sera (diluted 1:20) previously mixed with a $10^{-1}$ dilution of the inhibitor (rabbit anti-E2 ${ }_{661}$ serum). Binding of human IgG was detected as described above. The inhibition data were normalized to inhibition of binding by pre-immune serum. 


\subsection{Immunoprecipitation}

E ${ }_{661} \mathrm{E} 1_{340}$ was immunoprecipitated with H53 monoclonal antibody following the procedure previously used for $\mathrm{E} 1_{341} \mathrm{E} 2_{661}$ (Tello et al., 2010). The MAb H53 is conformation-dependent and was a generous gift of Dr. Jean Dubuisson. 


\section{Results}

\subsection{Expression and purification of $E 2_{661} E 1_{340}$}

The recombinant $\mathrm{E} 2{ }_{661} \mathrm{E} 1_{340}$ protein has 457 amino acids, 149 corresponding to positions $192-340$ of E1, 278 corresponding to positions $384-661$ of E2 and the rest being due to the cloning strategy, to the spacer-TEV sequence between E1 and E2, and to the amino-terminal His tag used to purify the protein (Fig. 1a).

The chimeric protein was expressed in High Five ${ }^{\mathrm{TM}}$ insect cells transfected with the pAcGP67A-E2 ${ }_{661} \mathrm{E} 1_{340}$ plasmid along with wild-type viral DNA. In a homologous recombination event, the $\mathrm{E} 2{ }_{661} \mathrm{E} 1_{340}$ gene was inserted into the viral genome. The protein was expressed by infecting a new batch of insect cells using amplified recombinant virus. Cells were grown and protocols were carried out as described in Materials and methods. As described for $E 1_{341} \mathrm{E} 2_{661}$ (Tello et al., 2010), the protein was expressed in a soluble form and secreted to the extracellular medium. However, the amount of the secreted E2E1 chimera was significantly higher than the observed for the E1E2 polypeptide when they were followed in an interval of 2-5 days of infection (Fig. 1b).

$\mathrm{E} 2_{661} \mathrm{E} 1_{340}$ secreted to the extracellular media was subsequently purified using affinity chromatography on a Ni-nitriliotriacetic acid-agarose column (Fig. 1c). The protein that elutes with $200 \mathrm{mM}$ imidazole was determined to be $>95 \%$ pure by densitometry of stained SDS gels. Furthermore, the purified protein was recognized by the monoclonal anti-His ${ }_{6}$ and anti-E1 antibodies and the polyclonal anti-E2 ${ }_{661}$ antibody (Fig. 1c). Following this procedure, approximately 7-8 mg of E2 ${ }_{661} \mathrm{E} 1_{340}$ 
protein were obtained from $1 \mathrm{~L}$ of culture media. This value represents 4 -fold the yield obtained for $\mathrm{E} 1_{341} \mathrm{E} 2_{661}$ (2 mg per liter) (Tello et al., 2010).

\subsection{Biochemical characterization of $E 2_{661} E 1_{340}$}

The amino acid composition of the recombinant secreted protein determined by aminoacid analysis was identical to that deduced from the cDNA sequence (data not shown). A value of 1.98 for $E^{0.1 \%}$ at $280 \mathrm{~nm}$ was experimentally calculated. Moreover, the first six Edman degradation steps of $\mathrm{E} 2{ }_{661} \mathrm{E} 1_{340}$ were identical to the theoretical sequence: ADPHHH. Then, the signal peptide gp67 has been correctly cleaved by cellular proteases, allowing the secretion of the processed protein.

SDS-PAGE analysis of the recombinant protein in the presence of reducing agents showed a single band with a molecular mass of $63 \mathrm{kDa}$ (Fig. 2b), while the theoretical mass based on the amino acid sequence is $50.5 \mathrm{kDa}$. Thus, as observed for $\mathrm{E} 1_{341} \mathrm{E} 2_{661}$ (Tello et al., 2010), $\mathrm{E} 2_{661} \mathrm{E} 1_{340}$ seems to be also glycosylated. In fact, when the recombinant protein was treated with PNGase F, which releases asparaginelinked (N-linked) oligosacharides from glycoproteins, the molecular mass of $\mathrm{E} 2{ }_{661} \mathrm{E} 1_{340}$ decreases to $53 \mathrm{kDa}$ (Fig. 2a). Nevertheless, carbohydrates were still detected with concanavaline A in treated recombinant protein with PNGase F (Fig. 2a), indicating that $\mathrm{E} 2_{661} \mathrm{E} 1_{340}$ must contain $\mathrm{N}$-glycosidic bonds which are not accessible to PNGase F or the presence of O-glycosidic bonds.

SDS-PAGE in the absence of reducing agents showed four main bands which have molecular masses that could correspond to monomeric, dimeric, trimeric and tetrameric forms of $\mathrm{E} 2{ }_{661} \mathrm{E} 1_{340}$ (Fig. 2b). Also, higher order structures which do not enter the gel were observed. However, when the gel was run in the presence of 
reducing agents only one band was observed that could correspond to the monomer (Fig. 2b). Therefore, $\mathrm{E} 2_{661} \mathrm{E} 1_{340}$ would self-associate at least through disulfide bridges. The same pattern of oligomerization was observed with the recombinant E1E2 glycoprotein (Tello et al., 2010).

\subsection{Spectroscopic analysis of $E 2_{661} E 1_{340}$}

The spectroscopic characterization of $\mathrm{E} 2_{661} \mathrm{E} 1_{340}$ and was carried out by means of circular dichroism and fluorescence spectroscopies and compared to those of $\mathrm{E} 1_{341} \mathrm{E} 2_{661}$. The far-UV CD spectra of both chimeric proteins were similar, showing a minimum at $208 \mathrm{~nm}$ (Fig. 3). Deconvolution of these spectra using the program Convex Constraint Analysis (CCA) (Perczel et al., 1991) indicated that both chimeric proteins have almost identical secondary structure (Table 1), with a high content in non-ordered structure (38-39\%), being the $\beta$-sheet the main ordered structure (Table 1). The predictive GOR IV method (Garnier et al., 1996), which is based upon the propensity of each amino acid to adopt a particular secondary structure, yielded a secondary structure for $\mathrm{E} 2_{661} \mathrm{E} 1_{340}$ and $\mathrm{E} 1_{341} \mathrm{E} 2_{661}$ which is not too different from the experimental one.

The fluorescence emission spectra of $\mathrm{E} 2_{661} \mathrm{E} 1_{340}$ and $\mathrm{E} 1_{341} \mathrm{E} 2_{661}$ were identical (Fig. 4). Upon excitation at $275 \mathrm{~nm}$, the recombinant proteins exhibited a maximum at $331 \mathrm{~nm}$, indicating that the fluorescence of these proteins is highly dominated by tryptophan residues and that they occupy a relatively hydrophobic environment. Upon excitation at $295 \mathrm{~nm}$, the position of the fluorescence emission maximum was around $330 \mathrm{~nm}$ for both proteins (data not shown). 
The difference between the fluorescence spectra obtained upon excitation at 275 and $295 \mathrm{~nm}$, the latter being normalized, indicates that the contribution of tyrosine residues to the recombinant protein fluorescence was very low, approximately $5 \%$, upon excitation at $275 \mathrm{~nm}$ (Fig. 4).

\subsection{Antigenic characterization of $E 2_{661} E 1_{340}$ and $E 1_{341} E 2_{661}$}

In order to assess the antigenic properties of $\mathrm{E} 2_{661} \mathrm{E} 1_{340}$, and compare to those of $\mathrm{E} 1_{341} \mathrm{E} 2_{661}$, a panel of eight $\mathrm{HCV}$-positive and ten $\mathrm{HCV}$-negative human sera were used in ELISA. Fig. 5 shows the results obtained for both proteins in assays performed at the same time and in the same conditions. The values of absorbance at $492 \mathrm{~nm}$ for all ten HCV-negative sera were almost negligible (data not shown). As it can be observed, the $\mathrm{A}_{492}$ values are generally very similar for both proteins, although a significant increase in the binding of IgGs present in sera 2, 3 and 6 to $E 2_{661} \mathrm{E} 1_{340}$ is detected. Nevertheless, these results suggest that the epitopes expressed in the surface of both proteins must be very similar.

On the other hand, Fig. 6 shows the results of an experiment of inhibition of the binding of both recombinant proteins to the antibodies present in the same eight HCV-positive, exerted by a polyclonal anti-E2 $2_{61}$ antibody. The inhibition experiments using the sera were carried out using a $10^{-1}$ dilution of the anti-E2 ${ }_{661}$ antibody. At this dilution, inhibition studies showed that the polyclonal anti-E2 ${ }_{661}$ antibody blocked the binding of the IgGs from the eight $\mathrm{HCV}$-positive sera at different levels. Thus, for sera 5 and 6 , the binding of $\operatorname{IgG}$ to $E 1_{341} \mathrm{E} 2{ }_{661}$ and $\mathrm{E} 2{ }_{661} \mathrm{E} 1_{340}$ was strongly inhibited by the anti-E2 ${ }_{661}$ antibody; in the cases of sera 3 and 7 significant difference were observed between both chimeras, with inverted 
inhibition percentages, higher in serum 3 for $E 2_{661} \mathrm{E} 1_{340}$, and higher in serum 7 for $\mathrm{E} 1_{341} \mathrm{E} 2_{661}$. These differences can be attributed to local variations in the exposure of some E2 epitopes in both chimeric proteins. However, in general the averages of inhibition, $62 \%$ for E2E1 and 69\% for E1E2, were once again very similar.

The conformation of the E2 moiety of the chimera was assessed with the monoclonal antibody $\mathrm{H} 53$ which is conformation-dependent. The chimeric protein was efficiently immunoprecipitated by the antibody indicating the native-like conformation of the E2 ectodomain. 


\section{Discussion}

The HCV envelope glycoproteins, E1 and E2, are the essential players for binding and entry of the virus into the cells. Consequently, they are the main focus of neutralizing antibodies and, hence, have become important targets for vaccine design. Leaving aside the importance of the transmembrane C-terminal regions of both proteins, it seems evident that recombinant glycoprotein E1 and E2 ectodomains can be a valuable tool to study the structure-function relationship of these polypeptides. In this regard, it has been described that the folding of the E2 ectodomain is independent of E1, but truncated E2 is required for the proper folding of E1 ectodomain ( Patel et al., 2001; Michalak et al., 1997). Hence, isolated properly folded E2 ectodomain produced either using the baculovirus-insect cell system (Rodriguez-Rodriguez et al., 2009) or using human HEK293 cells (Whidby et al., 2009) has been characterized and, very recently, the detailed structure of this truncated form bound to an antigen binding fragment has been described (Khan et al., 2014; Kong et al., 2013). Conversely, to date, no structural data of an isolated, properly folded, E1 ectodomain appears in the bibliography. In order to circumvent the problem, an alternative strategy has been to design a tandem chimeric polypeptide based on both E1 and E2 ectodomains. In a first attempt, a bacterially expressed chimeric protein E1E2, purified in presence of $6 \mathrm{M}$ Urea, was maintained soluble only after dialysis in the presence of both $0.1 \%$ Triton X-100 and $0.2 \%$ BSA, which precludes any subsequent structural study (Xiang et al., 2006). However, using the baculovirus system, the expression, secretion and purification in native conditions of the chimeric recombinant protein $\mathrm{E} 1_{341} \mathrm{E} 2_{661}$, containing the $\mathrm{E} 1$ and the E2 ectodomains linked by a hydrophilic and flexible FLAG sequence has been 
previously achieved (Tello et al., 2010). Biochemical, spectroscopical and antigenic characterization of this isolated chimeric polypeptide indicated that $E 1_{341} E 2_{661}$ behaved as a properly folded glycoprotein. Moreover, this chimera has been recently used as a tool to study the fusogenic properties of the HCV envelope proteins (Tello et al., 2014). In this report, a novel recombinant chimeric polypeptide, $\mathrm{E} 2_{661} \mathrm{E} 1_{340}$, has been produced. with both enveloped proteins permuted, and compared its properties with the described $\mathrm{E} 1_{341} \mathrm{E} 2_{661}$. Using the same baculovirus/insect cell system, E2 ${ }_{661} \mathrm{E} 1_{340}$ was secreted and purified with a yield, $(8 \mathrm{mg}$ per liter of culure media) similar to that described for the E2 ectodomain alone (Rodriguez-Rodriguez et al., 2009) which is at least four times the yield obtained for $E 1_{341} E 2_{661}$ (up to 2 $\mathrm{mg} / \mathrm{L}$ of culture). This considerable increase in the secretion of the processed protein when the E2 ectodomain is located in the amino terminal region of the chimeric polypeptide is another proof of the relevant role of the E2 ectodomain as a chaperone for the folding of E1.

Both chimeras contain the same E1 and E2 ectodomain sequences, but differ in the composition of the connecting hydrophilic peptide. The FLAG-enterokinase linker contained in $\mathrm{E} 1_{341} \mathrm{E} 2_{661}$ was substituted in $\mathrm{E} 2_{661} \mathrm{E} 1_{340}$ by a spacer-TEV protease recognition sequence with the aim to facilitate obtaining both domains in a separate and soluble form. This would be particularly interesting in the case of E1, since, as mentioned above, it has never been isolated in a native conformation. However, as occurred for $E 1_{341} \mathrm{E} 2_{661}$ after treatment with enterokinase, all attempts to cleave the TEV-cleavage site failed (data not shown) indicating the intricate interaction between both ectodomains.

Despite the difference between the linker region both $E 1_{341} \mathrm{E} 2{ }_{661}$ and $\mathrm{E} 2_{661} \mathrm{E} 1_{340}$, chimeric glycoproteins show very similar conformations. Thus, the 
circular dichroism far-UV spectrum showed that the recombinant proteins $E 1_{341} \mathrm{E} 2_{661}$ and $\mathrm{E} 2{ }_{661} \mathrm{E} 1_{340}$ share a high content of non-regular structure, with $\beta$-sheet as the major ordered secondary structure element. The $\alpha$-helix structure is present in a rather low percentage. This secondary structure is very similar to the recently described for the E2 ectodomain (Khan et al., 2014; Kong et al., 2013). On the other hand, the fluorescence emission maximum corresponding to the tryptophan residues of the proteins is centered at $331 \mathrm{~nm}$, indicating that these residues are located in a moderately hydrophobic environment. Taken together these results indicate that chimeric proteins have an open conformation, but different from a denatured state.

The results obtained in the antigenicity studies by ELISA using a panel of $\mathrm{HCV}$-positive human sera also indicated that both $\mathrm{E} 1_{341} \mathrm{E} 2{ }_{661}$ and $\mathrm{E} 2_{661} \mathrm{E} 1_{340}$ were specifically recognized by the IgGs present in these sera in a similar way. In sera with low ELISA signals, an increase in the binding to $\mathrm{E} 2{ }_{661} \mathrm{E} 1_{340}$ compared to $\mathrm{E} 1_{341} \mathrm{E} 2_{661}$ can be detected, especially significant for sera 2, 3 and 6, indicating that the chimera with permuted ectodomains showed even higher ability to bind to human antibodies. On the other hand, 6 out of 8 sera showed almost identical percentage of inhibition by anti $\mathrm{E} 2_{661}$ to the binding of both proteins. Thus, from the antigenic studies it can be concluded that the order of both E1 andE2 ectodomains in the polypeptide chain does not affect significantly the recognition by the antibodies present in the HCV-positive patient sera.

Regarding the oligomeric state of E2E1, SDS-PAGE in the absence of reducing agents showed four main bands which have molecular masses that could correspond to monomeric, dimeric, trimeric and tetrameric forms of $\mathrm{E} 2_{661} \mathrm{E} 1_{340}$, being the majority corresponding to the dimeric form. These results are indicative of a tendency to self-associate, a behavior that has already been reported not only for 
$\mathrm{E} 1_{340} \mathrm{E} 2_{661}$ (Tello et al., 2010), but also for the recombinant E2 ectodomain produced in the baculovirus/insect cell system (Rodriguez-Rodriguez et al., 2009). There is some controversy regarding the functionality of the HCV envelope glycoproteins and the formation of intermolecular covalent complexes. Although it has been described that the appearance of large covalent E1E2 complexes corresponds to nonfunctional aggregates (Op De Beeck et al., 2004), more recent studies, using the HCVcc system demonstrated the selective incorporation into secreted virions of large E1E2 disulfide-linked complexes that maintain a native conformation as they were able to bind conformation-sensitive neutralizing antibodies (Vieyres et al., 2010). Then, as for $E 1_{341} E 2_{661}$ and $E 2_{661}$, the disulfide-bridge oligomerization of $E 2_{661} E 1_{340}$ seems to be compatible with the maintenance of its native properties. Moreover, another proof of the correct conformation of the chimeric permuted glycoprotein is that, as observed for $\mathrm{E} 21_{341} \mathrm{E} 2661$ it was able to bind to human hepatome Huh7 cells through CD81 (data not shown).

In conclusion, the results described in this manuscript point out that $\mathrm{E} 2_{661} \mathrm{E} 1_{340}$ recombinant protein is properly folded like $\mathrm{E} 1_{341} \mathrm{E} 2_{661}$ and presents antigenic properties similar to E1 and E2 assembled in the HCV virion. Moreover, the high yield of production of this chimeric polypeptide will allow us to perform new structural and functional studies which will help to shed light on the infective cycle of HCV. Also, this recombinant protein may be used in immunization experiments to determine whether it can induce the production of neutralizing antibodies. 


\section{References}

Bartosch, B., Vitelli, A., Granier, C., Goujon, C., Dubuisson, J., Pascale, S., Scarselli, E., Cortese, R., Nicosia, A., Cosset, F.L., 2003. Cell entry of hepatitis C virus requires a set of co-receptors that include the CD81 tetraspanin and the SR-B1 scavenger receptor. J. Biol. Chem. 278, 41624-41630.

Brazzoli, M., Helenius, A., Foung, S.K.H., Houghton, M., Abrignani, S., Merola, M., 2005. Folding and dimerization of hepatitis C virus E1 and E2 glycoproteins in stably transfected CHO cells. Virology 332, 438-453.

Cocquerel, L., Meunier, J.-C., op de Beeck, A., Bonte, D., Wychowski, C., Dubuisson, J., 2001. Coexpression of hepatitis C virus envelope proteins E1 and E2 in cis improves the stability of membrane insertion of E2. J. Gen. Virol. 82, 16291635.

Feld, J.J., Hoofnagle, J.H., 2005. Mechanism of action of interferon and ribavirin in treatment of hepatitis C. Nature 436, 967-972.

Garnier, J., Gibrat, J.-F., Robson, B. 1996. GOR method for predicting protein secondary structure from amino acid sequence, in: R.F. Doolittle (Ed), Methods in Enzimology, Vol. 266, pp. 540-553.

Hüssy, P., Faust, H., Wagner, J.-C., Schmid, G., Mous, J., Jacobsen, H., 1997. Evaluation of hepatitis $\mathrm{C}$ virus envoloped proteins expressed in E. coli and insect cells for use as tools for antibody screening. J. Hepatol. 26, 1179-1186.

Hüssy, P., Schmid, G., Mous, J., Jacobsen, H., 1996. Purification and in vitrophospholabeling of secretory envelope proteins E1 and E2 of hepatitis C virus expressed in insect cells. Virus Res. 45, 45-57.

Imran, M., Manzoor, S., Khattak, N.M., Khalid, M., Ahmed, Q.L., Parvaiz, F., Tariq, M., Ashraf, J., Ashraf, W., Azam, S., Ashraf, M., 2014. Current and future 
therapies for hepatitis $\mathrm{C}$ virus infection: from viral proteins to host targets. Arch. Virol. 159, 831-846.

Khan, A.G., Whidby, J., Miller, M.T., Scarborough, H., Zatorski, A.V., Cygan, A., Price, A.A., Yost, S.A., Bohannon, C.D., Jacob, J., Grakoui, A., Marcotrigiano, J., 2014. Structure of the core ectodomain of the hepatitis C virus envelope glycoprotein 2. Nature 509, 381-384.

Kong, L., Giang, E., Nieusma, T., Kadam, R.U., Cogburn, K.E., Hua, Y., Dai, X., Stanfield, R.L., Burton, D.R., Ward, A.B., Wilson, I.A., Law, M., 2013. Hepatitis C virus E2 envelope glycoprotein core structure. Science 342, 10901094.

Laemmli, V.K., 1970. Cleavage of structural proteins during the assembly of the head of bacteriophage T4. Nature 227, 680-685.

Lindenbach, B.D., Rice, C.M., 2005. Unravelling hepatitis C virus replication from genome to function. Nature 436, 933-938.

Lorent, E., Bierau, H., Engelborghs, Y., Verheyden, G., Bosman, F., 2008. Structural characterisation of the hepatitis $\mathrm{C}$ envelope glycoprotein $\mathrm{E} 1$ ectodomain derived from a mammalian and a yeast expression system. Vaccine 26, 399-410.

Major, M.E., Rehermann, B., Feinstone, S.M. 2001. Hepatitis C viruses, in: Knipe, D., Howley, P.M. (Eds), Fields Virology. Lippincott Williams \& Wilkins, Philadelphia, pp. 1127-1161.

Michalak, J.-P., Wychowski, C., Choukhi, A., Meunier, J.-C., Ung, S., Rice, C.M., Dubuisson, J., 1997. Characterization of truncated forms of hepatitis C virus glycoproteins. J. Gen.Virol. 78, 2299-2306. 
Mizushima, H., Hijikata, M., Asabe, S., Hirota, M., Kimura, K., Shimotohno, K., 1994. Two hepatitis $\mathrm{C}$ virus glycoprotein $\mathrm{E} 2$ products with different $\mathrm{C}$ termini. J. Virol. 68, 6215-6222.

Mustilli, A.C., Izzo, E., Houghton, M., Galeotti, C.L., 1999. Comparison of secretion of a hepatitis C virus glycoprotein in Saccharomyces cerevisiae and Kluyveromyces lactis. Res. Microbiol. 150, 179-187.

Nielsen, S.U., Bassendine, M.F., Burt, A.D., Bevitt, D.J., Toms, G.L., 2004. Characterization of the genome and structural proteins of hepatitis $\mathrm{C}$ virus resolved from infected human liver. J. Gen. Virol. 85, 1497-1507.

Op De Beeck, A., Cocquerel, L., Dubuisson, J., 2001. Biogenesis of hepatitis C virus envelope glycoproteins. J. Gen. Virol. 82, 2589-2595.

Op De Beeck, A., Voisset, C., Bartosch, B., Ciczora, Y., Cocquerel, L., Keck, Z., Foung, S., Cosset, F.L., Dubuisson, J., 2004. Characterization of functional hepatitis C virus envelope glycoproteins. J. Virol. 78, 2994-3002.

Patel, J., Patel, A.H., McLauchlan, J., 2001. The transmembrane domain of the hepatitis C virus E2 glycoprotein is required for correct folding of the E1 glycoprotein and native complex formation. Virology 279, 58-68.

Perczel, A., Hollósi, M., Tusnády, G., Fasman, G.D., 1991. Deconvolution of the circular dichroism spectra of proteins: The circular dichroism spectra of antiparallel $\beta$-sheet in proteins. Protein Eng. 4, 669-679.

Ploss, A., Dubuisson, J., 2012. New advances in the molecular biology of hepatitis C virus infection: towards the identification of new treatment targets. Gut 61 Suppl $1, \mathrm{i} 25-35$.

Rodriguez-Rodriguez, M., Tello, D., Yelamos, B., Gomez-Gutierrez, J., Pacheco, B., Ortega, S., Serrano, A.G., Peterson, D.L., Gavilanes, F., 2009. Structural 
properties of the ectodomain of hepatitis C virus E2 envelope protein. Virus Res. $139,91-99$.

Sandrin, V., Boulanger, P., Penin, F., Granier, C., Cosset, F.L., Bartosch, B., 2005. Assembly of functional hepatitis $\mathrm{C}$ virus glycoproteins on infectious pseudoparticles occurs intracellularly and requires concomitant incorporation of E1 and E2 glycoproteins. J. Gen. Virol. 86, 3189-3199.

Tello, D., Rodriguez-Rodriguez, M., Ortega, S., Lombana, L., Yelamos, B., GomezGutierrez, J., Peterson, D.L., Gavilanes, F., 2014. Fusogenic properties of the ectodomains of hepatitis C virus envelope proteins. FEBS J. 281, 2558-2569.

Tello, D., Rodriguez-Rodriguez, M., Yelamos, B., Gomez-Gutierrez, J., Ortega, S., Pacheco, B., Peterson, D.L., Gavilanes, F., 2010. Expression and structural properties of a chimeric protein based on the ectodomains of E1 and E2 hepatitis C virus envelope glycoproteins. Protein Expr. Purif. 71, 123-131.

Vieyres, G., Thomas, X., Descamps, V., Duverlie, G., Patel, A.H., Dubuisson, J., 2010. Characterization of the envelope glycoproteins associated with infectious hepatitis C virus. J. Virol. 84, 10159-10168.

Wakita, T., Pietschmann, T., Kato, T., Date, T., Miyamoto, M., Zhao, Z., Murthy, K., Habermann, A., Krausslich, H.G., Mizokami, M., Bartenschlager, R., Liang, T.J., 2005. Production of infectious hepatitis $\mathrm{C}$ virus in tissue culture from a cloned viral genome. Nat. Med. 11, 791-796.

Whidby, J., Mateu, G., Scarborough, H., Demeler, B., Grakoui, A., Marcotrigiano, J., 2009. Blocking hepatitis C virus infection with recombinant form of envelope protein 2 ectodomain. J. Virol. 83, 11078-11089. 
Xiang, Z.H., Cai, W.J., Zhao, P., Kong, L.B., Ye, L.B., Wu, Z.H., 2006. Purification and application of bacterially expressed chimeric protein E1E2 of hepatitis C virus. Prot. Expres. Purif. 49, 95-101.

Zhong, J., Gastaminza, P., Cheng, G.F., Kapadia, S., Kato, T., Burton, D.R., Wieland, S.F., Uprichard, S.L., Wakita, T., Chisari, F.V., 2005. Robust hepatitis C virus infection in vitro. Proc. Natl. Acad. Sci. USA 102, 9294-9299. 


\section{FIGURE LEGENDS}

Fig. 1. (a) Schematic representation of the $E 2{ }_{661} E 1_{340}$ construction. (b) and (c) Analysis of the expression of $\mathrm{E} 2_{661} \mathrm{E} 1_{340}$ by High Five ${ }^{\mathrm{TM}}$ cells. (b) Secretion of $\mathrm{E} 1_{341} \mathrm{E} 2_{661}(\mathrm{O})$ and $\mathrm{E} 2_{661} \mathrm{E} 1_{340}(\bullet)$ chimeras upon 2-5 days infection. The amount of protein was measured by densitometry of anti-His-PO western blot band intensities. (c) (left) SDS-PAGE of purified $\mathrm{E} 2{ }_{661} \mathrm{E} 1_{340}$ recombinant protein. The sample was previously reduced with $5 \%(\mathrm{v} / \mathrm{v}) \beta$-mercaptoethanol and boiled for $5 \mathrm{~min}$. The gel was stained with Coomassie Brilliant blue R-250. (right) Western blot analysis of purified $\mathrm{E} 2_{661} \mathrm{E} 1_{340}$ using rabbit anti-E2 661 , and monoclonal anti-E1and anti-His 6 antibodies.

Fig. 2. Molecular characterization of $\mathrm{E} 2_{661} \mathrm{E} 1_{340}$. (a) Analysis of the deglycosylation of purified $\mathrm{E} 2_{661} \mathrm{E} 1_{340}$ by PNGase F. SDS-PAGE stained with Coomassie blue and concanavalin A (ConA) in absence (-) and presence (+) of PNGase F. Digestion with PNGase $\mathrm{F}$ was carried out at $37^{\circ} \mathrm{C}$ for $16 \mathrm{~h}$ in $20 \mathrm{mM}$ sodium phosphate $\mathrm{pH} 7.0,50$ mM EDTA, and 1\% (v/v) octylglucoside. (b) Oligomeric nature of E2 ${ }_{661} \mathrm{E} 1_{340}$. SDSPAGE of the purified $\mathrm{E} 2_{661} \mathrm{E} 1_{340}$ in presence or absence of $\beta$-mercaptoethanol. The positions of (a), monomer; (b), dimer; (c), trimer; (d), tetramer are marked. The gel was stained with Coomassie blue.

Fig. 3. Far-UV circular dichroism spectra of $E 2_{661} E 1_{340}$ and $E 1_{341} E 2_{661}$. The spectra were recorded in a cylindrical cuvette of $0.1 \mathrm{~cm}$ pathlength between 190 and $250 \mathrm{~nm}$ and the protein concentration was $0.15 \mathrm{mg} / \mathrm{ml}$. The buffer was $20 \mathrm{mM}$ Tris- $\mathrm{HCl} \mathrm{pH}$ 7, $50 \mathrm{mM} \mathrm{NaCl}$. Both spectra were recorded five times, averaged and corrected for 
buffer contributions. Data were collected at $25^{\circ} \mathrm{C}$ and are expressed as residue molar ellipticity.

Fig. 4. Fluorescence emission spectra of $E 2_{661} E 1_{340}$ and $E 1_{341} E 2_{661}$. The excitation wavelength was $275 \mathrm{~nm}\left(\mathrm{E} 2_{661} \mathrm{E} 1_{340}\right.$, open circles; $\mathrm{E} 1_{341} \mathrm{E} 2_{661}$, black circles). The emission spectra were recorded between 300 and $450 \mathrm{~nm}$. The contribution of Tyr residues (E2 $2_{661} \mathrm{E} 1_{340}$, open triangles; $\mathrm{E} 1_{341} \mathrm{E} 2_{661}$, black triangles) to the emission spectrum was calculated as described in the Materials and methods section. Protein

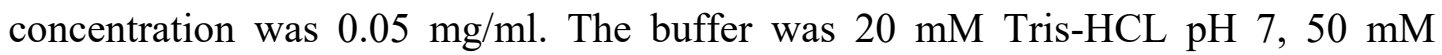
$\mathrm{NaCl}$. Spectra were collected at $25{ }^{\circ} \mathrm{C}$. The contribution of the buffer was always subtracted.

Fig. 5. ELISA with HCV-positive human sera. Microtitre wells were coated overnight at $4{ }^{\circ} \mathrm{C}$ with $\mathrm{E} 2_{661} \mathrm{E} 1_{340}$ or $\mathrm{E} 1_{341} \mathrm{E} 2_{661}$ recombinant proteins at $100 \mathrm{ng} / \mathrm{well}$. Eight HCV-positive human sera were used at a dilution of 1:20. Bound antibodies were detected with peroxidase conjugated anti-human $\operatorname{IgG}(\mathrm{Fc})$ diluted at 1:10000 as described in the Materials and methods section. The results shown are the means \pm standard deviations of three different experiments.

Fig. 6. Inhibition studies of the binding of $\mathrm{E} 2_{661} \mathrm{E} 1_{340}$ and $\mathrm{E} 1_{341} \mathrm{E} 2_{661}$ to $\mathrm{HCV}$ positive sera. A polyclonal rabbit anti-E2 $2_{661}$ antibody at $10^{-1}$ dilution was used to block the binding of the chimeric proteins to IgGs from $8 \mathrm{HCV}$-positive sera. The results shown are the means \pm standard deviations of three different experiments. 
Table 1.

Secondary structure of $\mathrm{E} 2_{661} \mathrm{E} 1_{340}$ and $\mathrm{E} 1_{341} \mathrm{E} 2_{661}$.

\begin{tabular}{ccccc} 
& \multirow{2}{*}{ The } & \multicolumn{2}{c}{ Experimental $^{\mathbf{a}}$} & \multicolumn{2}{c}{ Theoretical $^{\mathrm{b}}$} \\
\cline { 2 - 5 } & $\mathbf{E 1}_{\mathbf{3 4 1}} \mathbf{E 2}_{\mathbf{6 6 1}}$ & $\mathbf{E 2}_{\mathbf{6 6 1}} \mathbf{E 1}_{\mathbf{3 4 0}}$ & $\mathbf{E 1}_{\mathbf{3 4 1}} \mathbf{E 2}_{\mathbf{6 6 1}}$ & $\mathbf{E 2}_{\mathbf{6 6 1}} \mathbf{E 1}_{\mathbf{3 4 0}}$ \\
\hline$\alpha$-helix & 13 & 13 & 7 & 8 \\
$\beta$-sheet & 48 & 49 & 32 & 32 \\
non-ordered & 39 & 38 & 61 & 60 \\
\hline
\end{tabular}

experimental values were calculated from the far-UV CD spectrum by using the deconvolution program CCA (Perczel et al., 1991).

${ }^{\mathrm{b}}$ The theoretical values were calculated by GOR IV method (Garnier et al., 1996). 


\section{Figure 1}
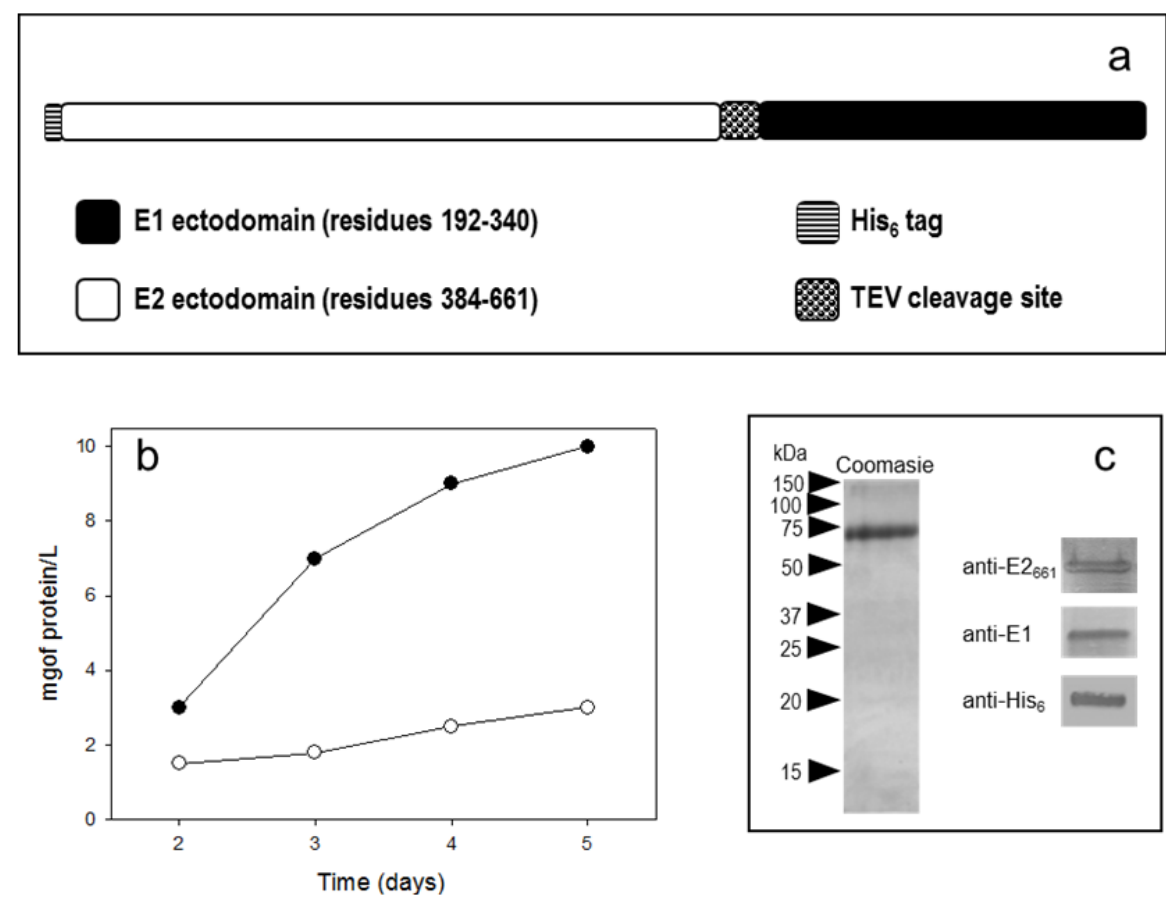
Figure 2
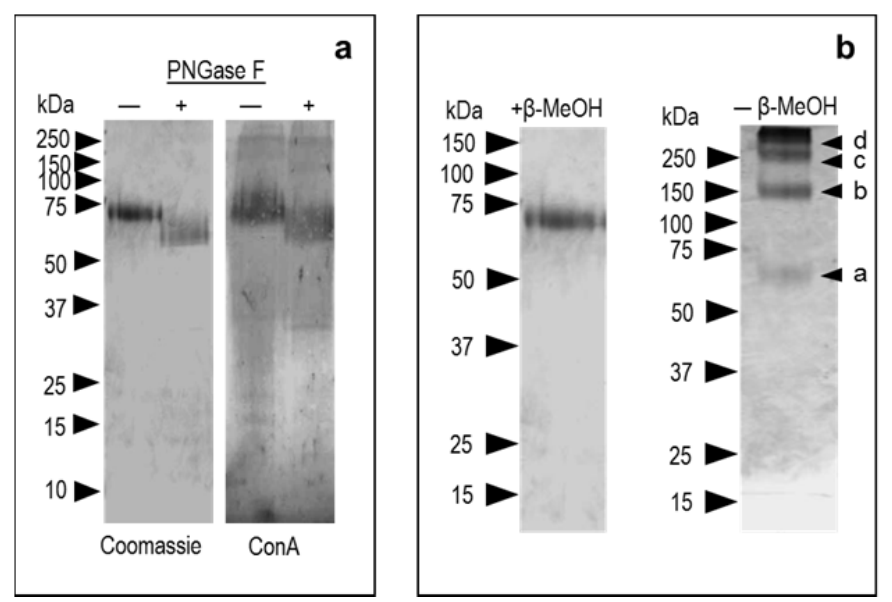
Figure 3

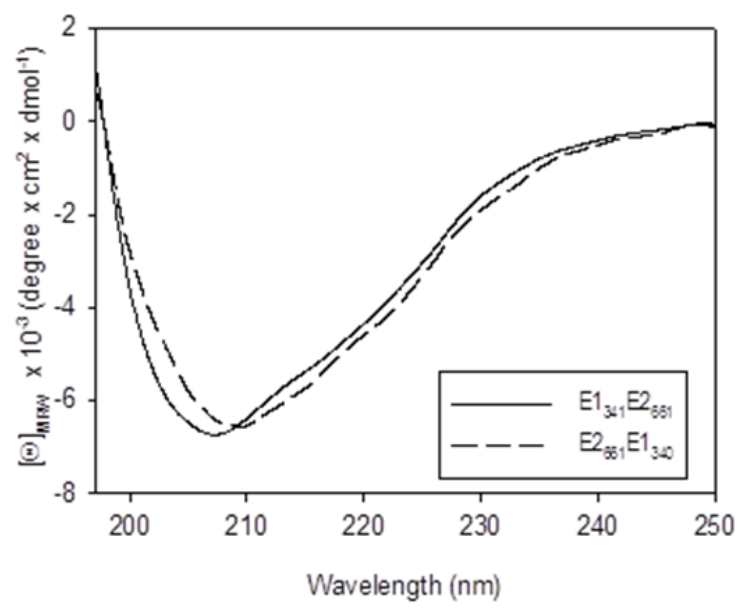


Figure 4

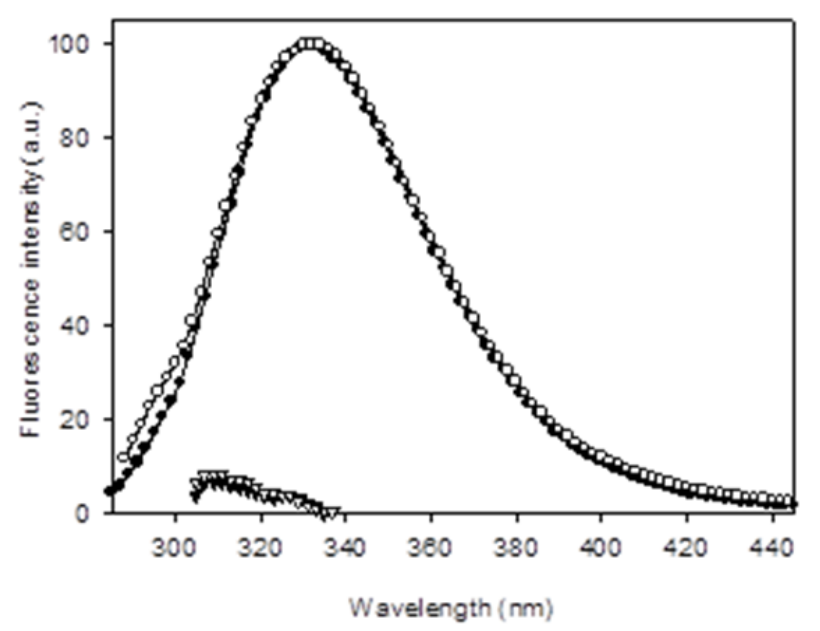


Figure 5

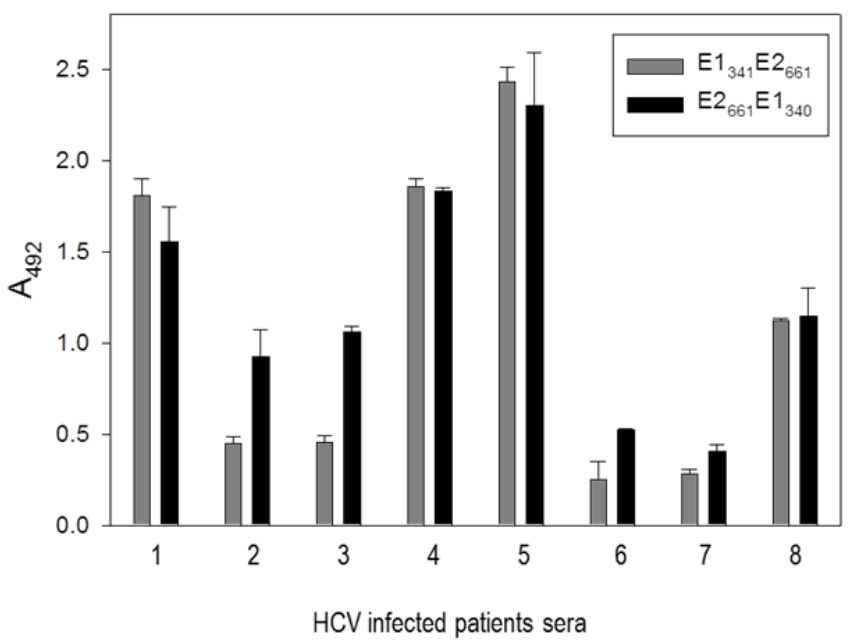


Figure 6

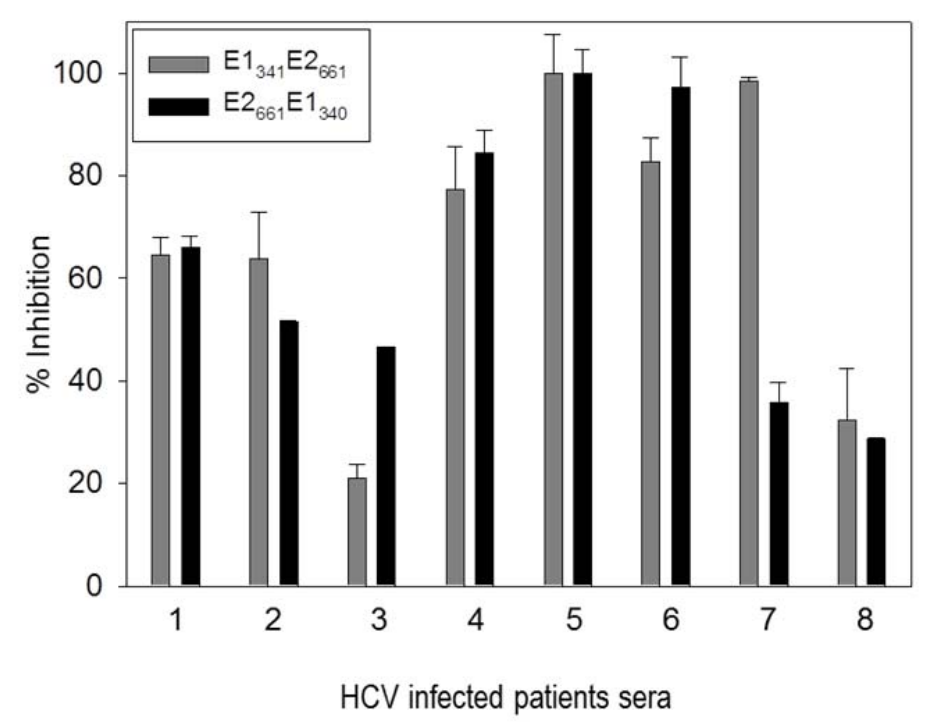

